\title{
Pensononowoor
}

2016, vol. 76, 117-125

http://dx.doi.org/10.12657/denbio.076.011

\author{
Martin Baláš, Ivan Kuneš, Josef Gallo, Nad’a Rašáková
}

\section{Review on Betula oycoviensis and foliar morphometry of the species in Volyně, Czech Republic}

\author{
Received: 14 October 2015; Accepted: 27 July 2016
}

\begin{abstract}
This contribution presents the results of the investigation of the Oyców birch (Betula oycoviensis Besser) population in Volyně, the Ore Mts., the only locality with its confirmed presence in the Czech Republic. The Volyně locality is situated ca $700 \mathrm{~m}$ ASL (mean temperature $6.5^{\circ} \mathrm{C}$, annual precipitation 700 $\mathrm{mm}$ ) mostly on nutrient-poor abandoned pastures. The aim of this paper is to present the results of geometric morphometric study on leaves and to summarize up to date knowledges on this tree species. We found and described altogether 58 individuals of Oyców birch during the field exploration. Dendrometric parameters, vitality and crown shape were analysed. To define characteristic morphological features of Oyców birch, we performed geometric morphometric method on leaves of selected 36 specimens. We found that 15 distinctive traits could be used to distinguish B. oycoviensis from Betula pendula Roth. The traits we considered most important are as follows: petiole length, number of major veins, blade length and blade width. These traits are in accordance with traits that common botanical field guides refer to. The appropriate management steps to support the natural regeneration of Oyców birch in the Volyně locality were recommended. To improve conditions for natural regeneration, grass sward removal in chosen spots is advisable. And finally, the artificial regeneration could be used to accelerate the propagation of the population.
\end{abstract}

Keywords: Oyców birch, geometric morphometrics, PCA analysis, threatened species, Ore Mts. (Krušné hory)

Address: M. Baláš, I. Kuneš, J. Gallo, N. Rašáková, Czech University of Life Sciences Prague, Faculty of Forestry and Wood Sciences, Department of Silviculture, Kamýcká 129, 16521 Prague, Czech Republic, e-mail: balas@fld.czu.cz

\section{Introduction}

The Betula L. genus (birch) is a very heterogeneous group including species of tree and shrubby habitus. It is well known that there is a possibility of interspecific hybridization and introgression within Betula genus (e.g. Johnsson, 1945; Sýkora, 1983; Eriksson
\& Jonsson, 1986; de Groot et al., 1997; Thórsson et al., 2001) and therefore a large amount of hybrid taxa were described. Some phylogenetical relationships among particular species are still unclear and the systematic status of some species is not yet explicitly defined (Schenk et al., 2008; Ashburner \& McAllis- 
ter, 2013); one such "obscure" and poorly described species being Oyców birch (Betula oycoviensis).

Oyców birch (Betula oycoviensis Besser) is a Central-European tree taxon which has been found in around 10 locations to date, each with micro-population of only several tens of individuals (Staszkiewicz, 2013). It is considered as a species of a natural heritage deserving full protection due its rarity and phylogenetically interesting fragmented distribution. Specifically, in the Czech Republic there is only one known locality near Volyně in the Ore Mountains (Krušné hory), (Kř́ǐz, 1981).

The general aim of the paper is to summarise the most important knowledge about Oyców birch (Betula oycoviensis), especially that gained from older literature sources. The next aim is to present the results of the morphometric analyses, focused on the Volyně birch population, in order to determine appropriate distinctive traits to distinguish between $B$. oycoviensis from $B$. pendula.

\section{Material and methods}

A field survey of the Oyców birch location in Volyně took place during summer 2013. The site is situated $680-720 \mathrm{~m}$ ASL (the coordinates: $\mathrm{N} 50^{\circ} 26.57^{\prime}, \mathrm{E} 13^{\circ} 13.12^{\prime}$ ) and comprised exposed nutrient-poor abandoned pastures, stony fallow lands and forest edges. Bedrock consists of orthogneiss and paragneiss (CGS, 2014). Basic climatic characteristic are as follows: long-term annual mean temperature $6.5^{\circ} \mathrm{C}$, long-term annual sum of precipitation ca 700 $\mathrm{mm}$ (Tolasz et al., 2007).

In 1986, this site was declared as a protected area of Natural Monument category named "Lokalita břízy ojcovské u Volyně" (i.e. "Locality of Oyców birch by Volyně"). The aim of conservation was to protect the only known location of occurrence of $B$. oycoviensis in the Czech Republic (at that time Czechoslovakia). The protected area consists of two separate parts, together making up 1.5 ha. According to previous investigations (Ondráček, 2008), only 23 individuals of Oyców birch were known in this locality.

Terminological note: The Natural Monument category according the Czech classification (AOPK, 2015) factually combines the IUCN Categories III and IV. The Volyně locality is analogous to the IUCN Category IV - habitat/species management area (IUCN, 1994; Dudley, 2008).

Detailed investigation of the birch population was undertaken inside the protected area as well as in its close vicinity. Together we described 58 trees, whose features corresponded with the characteristics of Oyców birch. We measured dendrometric parameters (height, DBH) and we visually evaluated vitality and branch shape of all trees found in the locality. Cate- gories used for indicative vitality (health status) assessment are as follows: 1. excellent vitality, 2 . good vitality, 3 . partially deteriorated vitality, 4 . noticeably deteriorated vitality, 5. dead tree.

Further, the GPS coordinates of each individual were recorded. Other ca 10 individuals were not included in our study due to their ambiguous characteristics (after visual assessment, we were not sure of their membership of the B. oycoviensis population). The total number of individuals on the location could be approximately 70 although it is possible that more individuals will be found and confirmed in future.

A sample of 36 individuals with typical features of Oyców birch was selected for further analyses. We also chose 17 local individuals of silver birch for comparison. Samples of branches and leaves were taken from the trees for comparative morphometric analysis. These samples were placed into herbarium for further processing using morphometrics. Two leaves from each branch were measured, i.e. four leaves per each investigated tree. Altogether 22 quantitative and qualitative traits were measured on each of the leaves. Measured traits are shown in Fig. 1. Presented methodology is derived from Ešnerová et al. (2012), a study which, in turn, was based on standard methodology used by e.g. Viscosi \& Cardini (2011); Gill \& Davy (1983) and by others.

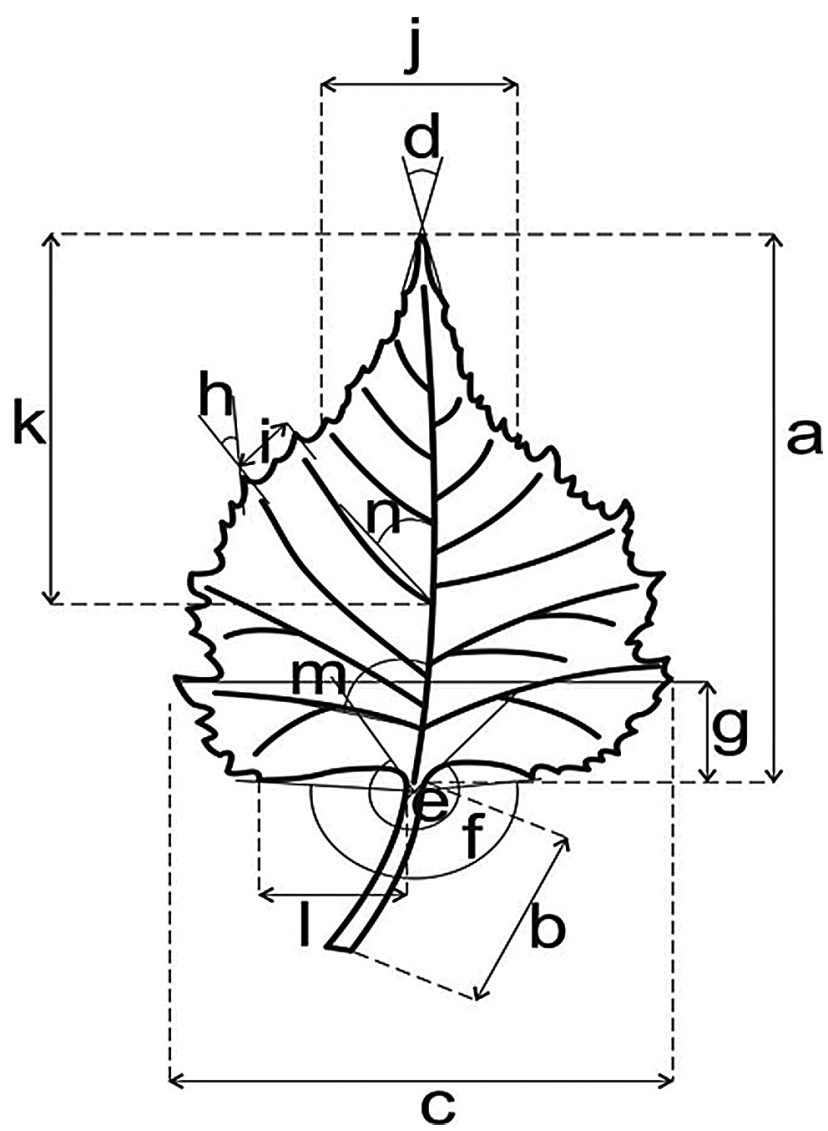

Fig. 1. Traits investigated on the leaves (according to Ešnerová et al., 2012) 
Table 1. List of investigated morphological traits

\begin{tabular}{|c|c|}
\hline Code & Trait \\
\hline & Quantitative traits \\
\hline a & Blade length $[\mathrm{mm}]$ \\
\hline $\mathrm{b}$ & Petiole length $[\mathrm{mm}]$ \\
\hline c & Blade width [mm] \\
\hline $\mathrm{d}$ & Angle of blade tip $\left[^{\circ}\right]$ \\
\hline $\mathrm{e}$ & Angle of blade fitting $\left[^{\circ}\right]$ \\
\hline $\mathrm{f}$ & Basal angle (to $1^{\text {st }}$ tooth) $\left[^{\circ}\right]$ \\
\hline $\mathrm{g}$ & Distance of widest part of blade from base [mm] \\
\hline $\mathrm{h}$ & Leaf serration angle $\left[^{\circ}\right]$ \\
\hline $\mathrm{i}$ & Distance between $3^{\text {rd }}$ and $4^{\text {th }}$ vein $[\mathrm{mm}]$ \\
\hline j & Blade width in the upper $1 / 4[\mathrm{~mm}]$ \\
\hline $\mathrm{k}$ & Distance from the $4^{\text {th }}$ vein to the tip $[\mathrm{mm}]$ \\
\hline 1 & Distance from the leaf base to the $1^{\text {st }}$ tooth edge \\
\hline $\mathrm{m}$ & Angle between the $1^{\text {st }}$ vein and midrib $\left[{ }^{\circ}\right]$ \\
\hline $\mathrm{n}$ & Angle between the $4^{\text {th }}$ vein and midrib $\left[^{\circ}\right]$ \\
\hline o & Number of major lateral veins \\
\hline \multirow[t]{8}{*}{$\mathrm{p}$} & Number of teeth between the $3^{\text {rd }}$ and the $4^{\text {th }}$ vein \\
\hline & Blade hairiness above [5-level scale, see notes] \\
\hline & Blade hairiness beneath [7-level scale, see notes] \\
\hline & Qualitative traits \\
\hline & Base shape [5 categories, see notes] \\
\hline & Type of serration [4-level scale, see notes] \\
\hline & Order of veins [paired $\times$ non paired] \\
\hline & Base symmetry [symmetry $\times$ asymmetry] \\
\hline
\end{tabular}

Notes:

Scale used for assessment of the trait blade hairiness above: 1 - hairy blade on whole surface, 2 - blade with scattered hairs on whole surface, 3 - hairy blade on veins, 4 - blade with hairs on veins, 5 - glabrous blade.

Scale used for assessment of the trait blade hairiness beneath: 1 hairy blade on whole surface, 2 - blade with scattered hairs on whole surface, 3 - hairy blade on veins, 4 - blade with scattered hairs on veins, 5 - blade hairy on axil, 6 - blade with scattered hairs on axil, 7 - glabrous blade.

Categories used for assessment of the trait shape of base: 1 - heart shaped (deep $>2 \mathrm{~mm}$ ), 2 - almost heart shaped (deep 0-2 $\mathrm{mm}), 3$ - round shaped, 4 - cut off, 5 - wedge shaped.

Categories used for assessment of the trait type of serration: 1 individual, 2 - individual up to lightly doubled, 3 - doubled, 4 - extremely doubled.

Table 1 contains the list of investigated morphological traits included in the principle component analysis (PCA) on Fig. 3.

Measured traits were selected with respect to outcomes of studies by other authors (e.g. Gill \& Davy, 1983). Geometric traits on leaves were measured with ruler to the nearest $1 \mathrm{~mm}$ and protractor to the nearest $1^{\circ}$. Hairiness was determined with binocular microscope. Obtained values were further processed in program R (R Development Core Team, 2011). Fisher's exact test was applied for parameters that acquire only two alternative values. $\mathrm{X}^{2}$ (Chi-Square test) Test of Independence was used for data in contingency table (traits assessed by scales). Principal Component Analysis (PCA) was carried out in CANOCO for Windows 5 (ter Braak \& Šmilauer, 2002).

\section{Results}

\section{History and distribution of Oyców birch}

Oyców birch (Betula oycoviensis Besser) is a tree taxon commonly considered to be closely relative to silver birch (Betula pendula Roth). According to the literature sources (Jentys-Szaferowa, 1953; Kř́iž, 1981), Oyców birch was first found in 1805 by Willibald Swibert Joseph Gottlieb von Besser; the morphological description was published in Besser (1809). However, this original description was not officially registered. Krŕiž (1981) further presents that individuals of Oyców birch were later found and documented several times at various locations (e.g. in 1859 by botanist F. Berdau, in 1861 by E. Regel, in 1866 by P. J. F. Schur, in 1912 by Z. Woycicki and by others), but the taxonomical classification of these specimens remained inconsistent. The determination of Oyców birch as a species came much later (in 1920), namely by Polish botanist J. Jentys-Szaferowa, and officially published in Szaferowa (1928).

Oyców birch was initially considered an endemic species. The original habitat (i.e. locus classicus) was the Hamernia locality in Giebułtów near Kraków in Poland. Further studies refuted the endemic character since other sites of occurrence were discovered in Poland (e.g. Turałówna, 1957; Krzaczek \& Krzaczek, 1968). Later on, Oyców birch was recorded in several localities in Sweden, Austria, Romania, Denmark, Ukraine, the Czech Republic and even in the middle of Russia (Korczyk, 1967a; Staszkiewicz \& Wójcicki, 1992; Staszkiewicz, 2013). Nevertheless, Oyców birch is very rare because the number of individuals in separated local populations is often very low. Unfortunately, the population of Oyców birch at Hamernia locus classicus steadily declined, mainly due to forest succession (Staszkiewicz \& Wójcicki, 1986), thus there have been found no individuals reported since the end of the 1990s (Soltys-Lelek \& Barabasz-Krasny, 2009). In any case, its widely fragmented distribution causes the questions about the genesis of this taxon. It could theoretically be a relic from a formerly more abundant population, random spreading on long distances from one centre, anthropogenic transfer (at least in some locations) or an independent emergence of the same type of hybrid in different places. It is possible, however, that $B$. oycoviensis might be more abundant than previously thought and is elusive because of its inconspicuous appearance and therefore could have remained undetected and undistinguished.

In the region of today's Czech Republic, B. oycoviensis was collected and deposited into herbarium for the first time in 1842-1843 by botanist J. Knaf. However, historical herbarium samples were identified and properly distinguished much later (Korczyk, 
1967a). Based on these historical records, the B. oycoviensis specimens were found again in 1977 in the Volyně locality in the Ore Mts. (Krušné hory), (Kř́̌ž, 1980; Kř́rž, 1981).

\section{Taxonomy}

The taxonomy of Betula L. genus is generally complicated and there are some doubts whether Oyców birch can be classified as a species, or whether it is another (lower) taxonomic unit. It is also possible that the findings mentioned in the following review will be reconsidered by the future studies following modern genetic methods. Nevertheless, we are working on the assumption that this taxon is officially classified on the level of species, according to valid Czech botanic classification (Kř́iž, 2003). Moreover, the current Polish dendrology literature (Seneta \& Dolatowski, 1997) also confirms Oyców birch as a species.

The species of Betula oycoviensis Besser is supposedly a hybrid emerged from the crossing of silver birch (Betula pendula Roth.) and Szafer's birch (Betula szaferi Jent.-Szaf. ex Stasz.), (e.g. Staszkiewicz, 1986; Staszkiewicz \& Wójcicki, 1992). Controlled crossing of both Betula oycoviensis $\times$ Betula oycoviensis resulted in progeny of 3 types: $1^{\text {st }}$ type: verrucosa (pendula); $2^{\text {nd }}$ type: oycoviensis; and $3^{\text {rd }}$ type: "nova" (e.g. Jentys-Szaferowa, 1967; Szwabowicz, 1971; Szwabowicz, 1976). The type "nova" was later named Betula szaferi (Staszkiewicz, 1986). The genome of Betula oycoviensis and of mentioned hybrid taxa has 28 chromosomes $(2 n=28)$ (Szwabowicz, 1972). The hybrids of B. oycoviensis and B. pendula have overall features similar to $B$. pendula (Jentys-Szaferowa, 1953). The bidirectional crossing of Betula "nova" (i.e. Betula szaferi) and $B$. pendula yielded uniform progeny with characteristics of B. oycoviensis (Jentys-Szaferowa, 1967; Szwabowicz, 1976) and also the bidirectional crossing of Betula "nova" and B. oycoviensis yielded typical B. oycoviensis progeny (Jentys-Szaferowa et al., 1974). This shows that the individuals of "nova" (B. szaferi) and B. pendula are parents of B. oycoviensis (Staszkiewicz, 1986). The biochemical study (Pawłowska, 1980b) confirmed this presumption.

The distribution of B. szaferi is confined to Poland. Free-growing individuals were discovered also in 1967 in the Kobylańska Valley locality (Staszkiewicz, 1986), always close to individuals of B. oycoviensis (Korczyk, 1967b). However, currently no wild populations of B. szaferi are known, but there is a specimen planted in Krakow Botanical Garden (IUCN, 2014). Regarding to the genesis of $B$. szaferi, some studies referred to its close relationship with $B$. humilis Schrank (Gardiner \& Jeffers, 1962; Staszkiewicz, 1986). However, later study (Pawłowska, 1980a) this parental relationship probably excludes. However, the proximity of B. szaferi and several of North-American birch species was revealed (Pawłowska, 1983).

In the Czech locality in Volyně, it was confirmed that this Oyców birch population belongs to the same taxon as the Polish populations (Kř́iž, 1981). However, especially due to the disrupted area, still we cannot be sure whether these populations are of the same species (taxa), or whether they are of different taxa which are considerably morphologically similar. Nonetheless, before addressing the problem of genetic classification of the Czech population (using molecular genetic methods), it was considered necessary to describe the population and distribution of its individuals in detail.

\section{Morphology}

Usually Oyców birches have a shrubby habitus (height around $4 \mathrm{~m}$ ), but they can also occur as smaller trees reaching up to $15-20 \mathrm{~m}$ in height (Jentys-Szaferowa, 1953; Staszkiewicz \& Wójcicki, 1992). The stem bark is, similarly to silver birch, mostly white or in some cases darker (Białobok, 1979). The bark of older trees is often deeply cracked towards the lower part of stem (Staszkiewicz, 2013). Thin branches are distinctively glandular displaying reddish to greyish-brown bark. Crown is usually ovoid and considerably irregular, denser and thinner, stem is often curved. Epicormic branches (shoots) and dormant buds are common (Seneta \& Dolatowski, 1997), while root suckers, on the other hand, do not occur. Typical appearance of Oyców birches in Volyně locality is depicted on Fig. 2.

Annual shoots are mostly hairless, with markedly long brachyblasts and tiny oval-shaped buds are usually sticky (Kř́iž, 2003). Leaves grow from shortened branches and they are finer compared to B. pendula, their size being mostly $10-40 \mathrm{~mm}$ long and 5-30 $\mathrm{mm}$ in wide. The angle between the leaf base and the main veins is $40-90^{\circ}$ and young leaves (leaves on young shoots) are initially sticky and fairly hairy. The petioles are very thin and mostly relatively long compared to the dimension of leaves (Staszkiewicz, 2013). The common number of major lateral veins is 4-6 pairs (Staszkiewicz \& Wojcicki, 1992). Shortened branches that carry catkins are twice as long compared to those in B. pendula and they usually have 2-9 leaves (Jentys-Szaferowa, 1953).

Birches are monoecious and wind-pollinated species. Male catkins of $B$. oycoviensis are individual or up to three in a cluster, $2-5 \mathrm{~cm}$ in length during flowering, while female catkins (cones) are around $2 \mathrm{~cm}$ long and grow on brachyblasts (Kříž, 2003). Cone scales are trilobate, dimension ca $5 \mathrm{~mm}$, and are usually wider than long. Seeds (fruits - achenes) are wider than in B. pendula. They are braided by side wings commonly 1.5-2 times wider than an achene. 
The flowering time of $B$. oycoviensis is similar to other species, from April to May, and the leaves burst at the same time (Staszkiewicz, 2013). Fructification usually commences at an early age, normally from the third year. The cones with fruits often stay on the trees until the following year (Jentys-Szaferowa, 1953), with this being an important distinctive trait from $B$. pendula during the winter period and in its juvenile stage.

It is supposed that the site-demands of B. oycoviensis are similar to $B$. pendula, as they often occur together. It is a pioneer, heliophilous species, growing on various types of sites, involving rocky (Úradníček et al., 2009), loamy (Staszkiewicz, 2013) and nutrient poor soils, in addition to dry conditions.

It is evident that the potential for commercial use of Oyców birch in forestry is close to zero, considering its slow growth and rather dwarfed habitus. On the other hand, these features should bring some benefits in ornamental arboriculture. Undoubtedly, especially considering its very rare natural distribu-

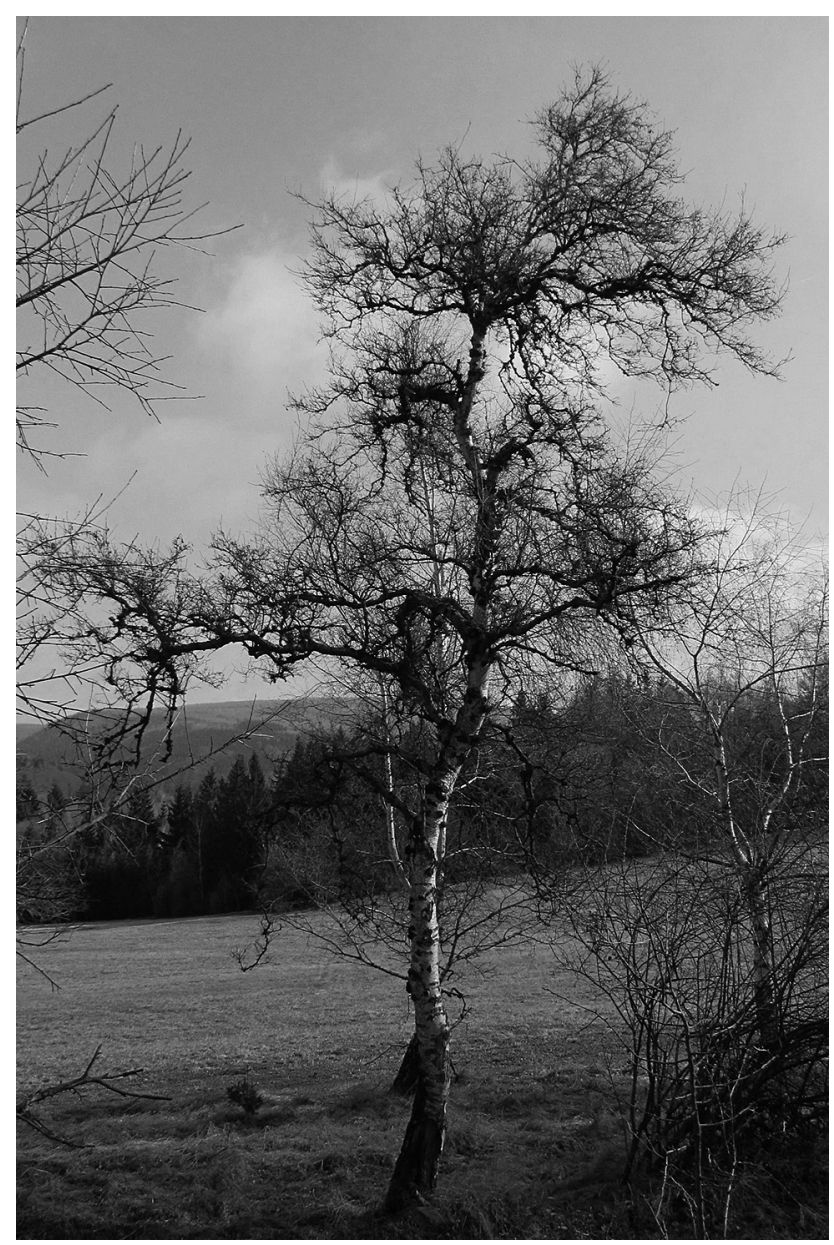

Fig. 2. Typical appearance of birches in Volyně locality which are determined as the Oyców birch. Characteristic features are especially as follows: dwarfed crown, curved stem and branches with high abundance of epicormic shoots and dormant buds (photo by M. Baláš) tion, Oyców birch could be enormously attractive for botanical gardens and parks.

In regard to its unclear taxonomic classification and phylogenetic circumstances, there is obvious motivation for more detailed research of B. oycoviensis. A crucial matter for further research is the ability for a clear recognition of B. oycoviensis and B. pendula based on morphological traits, as a leaf shape is one of important distinctive traits in taxonomy and plant classification system (e.g. Bell \& Bryan, 2008). To assess differences in leaf shape, classic morphometric methods are often used (Viscosi \& Cardini, 2011). Investigation of profiles, independent from size of the object, is also needed. This approach is developed in geometric morphometric analysis (geometric morphometrics), which is based on the investigation of relative positions of anatomic points that can be used for spacing of curves and planes (Jensen, 2003). The differences in shapes can be expressed in graphics; i.e. particular contours and graphic expression of mutual relations (Adams et al., 2004). Use of genetic and morphologic studies in taxonomy and other fields can be effective for understanding the origins of phenotypic differences (Klingenberg, 2010).

\section{Volyně population survey}

Through the investigation in the Volyně locality, approximately 70 individuals of Oyców birch were identified, which included approximately 40 new individuals compared to previous data (Ondráček, 2008). However, there is a relatively high probability of the occurrence of more individuals nearby, as another reference (Kř́iž, 1981) briefly mentions several hundreds of individuals in the wider surroundings.

Altogether 58 individuals were described in detail. Mean height was $7.3 \mathrm{~m}$ (standard deviation 3.2), mean $\mathrm{DBH}$ reached $10.8 \mathrm{~cm}$ (st. dev. 5.9). There were 17 trees smaller than $5 \mathrm{~m}$ and 9 trees higher than $10 \mathrm{~m}$, the height of the remaining (33 trees) was between 5 and $10 \mathrm{~m}$. The health status of most of the individuals was relatively good. The proportion of trees with excellent and good vitality is 34 and $36 \%$, respectively; the partially and noticeably deteriorated vitality was found in 25 and $5 \%$ of trees, respectively; no dead trees were found. The trees do not seem to be in an imminent danger by the existing management of the area. On the other hand, the natural regeneration of Oyców birch is very restricted in this locality due to dense grass sward, therefore only a few seedlings were found.

We recorded $51 \%$ of trees showing the heterogeneity of crown shape and branching type. One part of the tree crown (mostly the lower part ) had traits typical for Oyców birch (curved and dense branching, dormant buds, epicormic shoots) and the rest of crown had an appearance of silver birch (bigger 
leaves, pendant, but sometimes even upright branches). The tree shape can be analogous as the graft of another cultivar would be transplanted on the rootstock.

\section{Morphometric analyses of the Volyně population}

Principal Component Analysis, which encompassed 16 measured traits, was carried out for all individuals included in herbarium. Four qualitative traits and hairiness of blade hairiness above and beneath were not included in this analysis because of their binomial character.

Fig. 3 shows that there were evident differences between the taxa B. oycoviensis and B. pendula in foliar morphology. Recorded values for Oyców birch were distinctively lower in comparison with silver birch. The overview of morphometry results is shown in Table 2.

The classic morphometric analysis, which is capable of determining the species (based on morphological traits) proved to be successful in distinguishing $B$. pendula from $B$. oycoviensis. The significant differences were revealed in the majority of together 22 investigated traits.

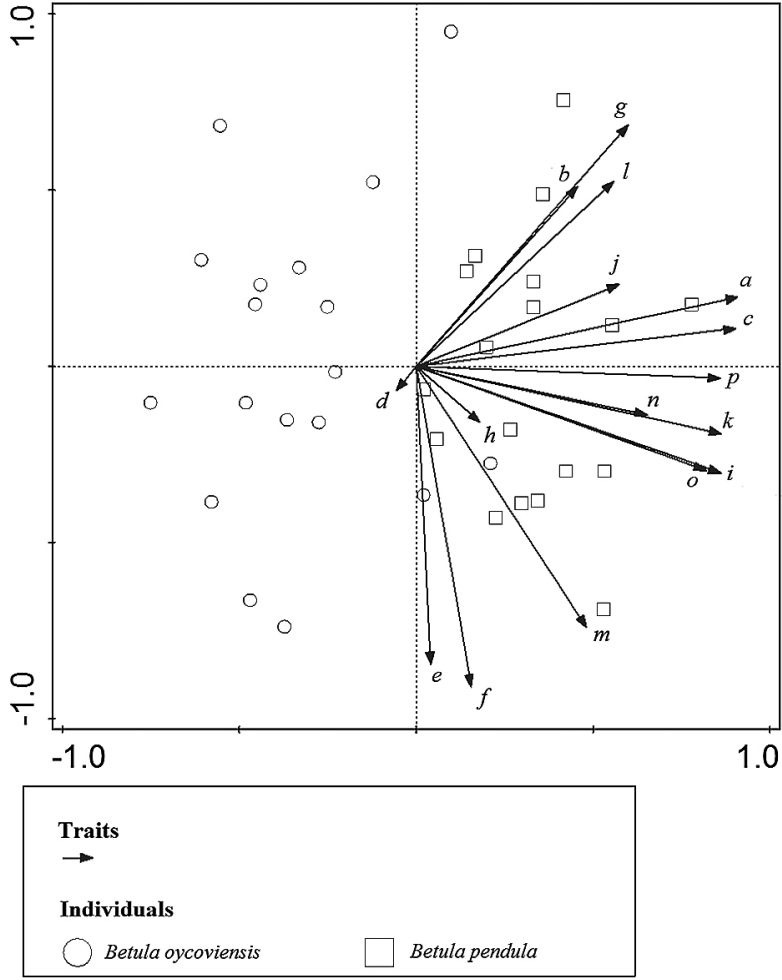

Fig. 3. Principal component analysis of traits measured on birch leaves (for notes see Table 1)

Table 2. Mean values of investigated features for Betula oycoviensis (BO) and Betula pendula (BP). Codes are done according to Table 1

\begin{tabular}{|c|c|c|c|c|}
\hline Code & Trait & Mean value (BO) & Mean value (BP) & Significance \\
\hline \multicolumn{5}{|c|}{ Quantitative traits } \\
\hline $\mathrm{a}$ & Blade length [mm] & 31.37 & 42.66 & $* * *$ \\
\hline $\mathrm{b}$ & Petiole length $[\mathrm{mm}]$ & 12.53 & 14.46 & * \\
\hline c & Blade width $[\mathrm{mm}]$ & 24.69 & 32.86 & $* * *$ \\
\hline $\mathrm{f}$ & Basal angle (to $1^{\text {st }}$ tooth) $\left[^{\circ}\right]$ & 302.94 & 311.41 & * \\
\hline g & Distance of widest part of blade from base $[\mathrm{mm}]$ & 11.58 & 13.87 & $* * *$ \\
\hline $\mathrm{i}$ & Distance between $3^{\text {rd }}$ and $4^{\text {th }}$ vein $[\mathrm{mm}]$ & 3.47 & 5.61 & $* * *$ \\
\hline j & Blade width in the upper $1 / 4[\mathrm{~mm}]$ & 8.4 & 10.58 & $* * *$ \\
\hline $\mathrm{k}$ & Distance from $4^{\text {th }}$ vein to the tip $[\mathrm{mm}]$ & 8.31 & 19.91 & $* * *$ \\
\hline 1 & Distance from leaf base to $1^{\text {st }}$ tooth edge $[\mathrm{mm}]$ & 11.31 & 14.03 & $* * *$ \\
\hline $\mathrm{m}$ & Angle between $1^{\text {st }}$ vein and midrib $\left[{ }^{\circ}\right]$ & 48.43 & 52.68 & $* *$ \\
\hline $\mathrm{n}$ & Angle between $4^{\text {th }}$ vein and midrib $\left[{ }^{\circ}\right]$ & 27.21 & 34.81 & $* *$ \\
\hline o & Number of major lateral veins & 4.16 & 5.53 & $* * *$ \\
\hline $\mathrm{p}$ & Number of teeth between $3^{\text {rd }}$ and $4^{\text {th }}$ vein & 0.43 & 1.43 & $* * *$ \\
\hline $\mathrm{d}$ & Angle of blade tip $\left[^{\circ}\right]$ & 31.57 & 29.73 & ns. \\
\hline e & Angle of blade fitting $\left[{ }^{\circ}\right]$ & 303.39 & 311.06 & ns. \\
\hline \multirow[t]{3}{*}{$\mathrm{h}$} & Leaf serration angle $\left[{ }^{\circ}\right]$ & 35.5 & 35.9 & ns. \\
\hline & Blade hairiness above [5-level scale] & 5 & 5 & ns. \\
\hline & Blade hairiness beneath [7-level scale] & 7 & 7 & ns. \\
\hline \multicolumn{5}{|c|}{ Qualitative traits } \\
\hline & Base shape [5 categories] & & & * \\
\hline & Type of serration [4-level scale] & & & $* * *$ \\
\hline & Order of veins [paired $\times$ non paired] & & & ns. \\
\hline & Base symmetry [symmetry $\times$ asymmetry] & & & ns. \\
\hline
\end{tabular}

Number of measured trees: Betula oycoviensis: 36 , Betula pendula: 17; $\mathrm{P}-$ significance levels: ${ }^{* * *} \mathrm{p}<0.001 ;{ }^{* *} \mathrm{p}<0.01 ;{ }^{*} \mathrm{p}<0.05$; ns. non-significant $(\mathrm{p}>0.05)$. 


\section{Discussion}

For practical determination of birches in the field it is important to find traits that sufficiently differ between the species to be distinguished from each other. An important trait quoted in botanical field guides (Kř́žz, 2003; Staszkiewicz, 2013) for distinguishing these birches ( $B$. alba vs. B. oycoviensis) is the petiole length. Although our study accepted this trait as significant $(p=0.016)$, it recognized other assessed traits as more important to distinguish the compared birch species. The number of major veins is another trait referred to as important in the literature (Kř́iž, 2003; Seneta \& Dolatowski, 1997). Our study confirmed its significance $(\mathrm{p}<0.001)$. The blade length and blade width are often presented as determination traits (Staszkiewicz, 2013) which is in compliance with the results of our study. In this study, these traits are also considered statistically significant at $\alpha=0.001$ significance level.

The interesting finding was the heterogeneity of branch shape in about $1 / 2$ of individuals. The similar phenomenon has already been described in older literature (Jentys-Szaferowa, 1953) and according to her hypothesis, we can speculate about the spontaneous changing of ploidy in some parts of tree body. The occurrence of a polyploid formation is known in many flowering plant species (e.g. Ramsey \& Schemske, 1998; Parisod et al., 2010). Although the ploidy of B. oycoviensis is commonly $2 \mathrm{n}=28$, the study performed by Szwabowicz (1972) revealed the mixoploidy character in case of two B. oycoviensis specimens when beside the cells with 28 chromosomes, some cells of very young leaves with 25 to 56 chromosomes also occurred.

Even though the number of Oyców birch individuals in Volyně locality is most likely higher than stated previously, it is still a very small population, which is unique within the Czech Republic. The threat for some trees is the dense canopy of other woody plants, meaning in some sites it will be desirable to release the canopy by silvicultural measures. In regard to the expected occurrence of Oyców birch in the close surroundings of the protected area, there is a risk of their removal during forest tending harvests. It is therefore desirable that the loggers and other workers are trained to recognize individuals of Oyców birch from those of silver birch.

\section{Conclusion}

The study was aimed at the investigation of Oyców birch (Betula oycoviensis Besser) in the only locality of this species in the Czech Republic (Volyně, the Ore Mts., Krušné hory). The results of leaf morphology show that it is possible to reliably distinguish between B. pendula and B. oycoviensis. Petiole length, blade length and blade width were some of the significantly different traits.

Around 70 individuals of Oyców birch were found during field investigation. Nevertheless, it is necessary that the birch is considered as a threatened species, and it is desirable to treat it with special care and ensure appropriate protection for the current population and support the propagation. The importance of Oyców birch for commercial forestry is negligible, but taking into consideration its interesting habitus, it has some potential in ornamental gardening and amenity greenery, and of course, biodiversity value.

\section{Ackonowledgements}

The study was supported by Ministry of Agriculture of the Czech Republic (research projects NAZV No. QH92087 and QJ1220331) and Czech University of Life Sciences Prague (project CIGA No. 20104308). The authors would like to thank to the members of the research team who participated in the study. We thank to Mr. M. Drury (National School of Forestry, University of Cumbria, Newton Rigg, United Kingdom) for proofreading of the manuscript. The sowings of seeds and in-vitro cultivation are being carried out in the Truba Research Station in Kostelec nad Černými lesy (Department of Silviculture, Faculty of Forestry and Wood Sciences, CULS Prague). Special thanks go to Mrs. M. Molitorová (Litoměřice Regional Museum) and to Mrs. R. Lichtenberková (Regional Museum in Chomutov).

\section{References}

Adams DC, Rohlf FJ \& Slice DE (2004) Geometric morphometrics: Ten years progress following the ,revolution'. Italian Journal of Zoology 71: 5-16. doi:10.1080/11250000409356545.

Ashburner K \& McAllister HA (2013) The Genus Betula - A Taxonomic Revision of Birches. Royal Botanic Garden, Kew, Richmond, Surrey, UK.

AOPK (2015) Territorial conservation. Agentura ochrany přírody a krajiny. Nature Conservation Agency of the Czech Republic. http://www. ochranaprirody.cz/en/what-we-do/territorial-conservation.

Bell AD \& Bryan A (2008) Plant Form: An Illustrated Guide to Flowering Plant Morphology. London, Timber Press.

Besser WSJG (1809) Primitiae florae Galiciae Austriacae utriusque. Anton Doll Verlag, Wien.

Białobok S (1979) Brzozy: Betula L. Państwowe Wydawnictwo Naukowe, Poznań. 
de Groot WJ, Thomas PA \& Wein RW (1997) Betula nana L. and Betula glandulosa Michx. Journal of Ecology 85: 241-264.

CGS (2014) Geological map 1:50 000. On-line maps. Czech Geological Survey, Prague. http://mapy.geology.cz/geocr 50

Dudley N (2008) Guidelines for applying protected area management categories. International Union for Conservation of Nature and Natural Resources, Gland, Switzerland.

Eriksson G \& Jonsson A (1986) A review of the genetics of Betula. Scandinavian Journal of Forest Research 1: 421-434.

Ešnerová J, Karlík P, Zahradník D, Koňasová T, Stejskal J, Baláš M, Vítámvás J, Rašáková N, Stacho J, Kuthan J, Lukášová M \& Kuneš I (2012) Morfologická variabilita rodu bříza (Betula L.) v Krkonoších se zaměřením na tetraploidní zástupce. Zprávy lesnického výzkumu 57: 112-125.

Gardiner AS \& Jeffers JNR (1962) Analysis of the collective species Betula alba $\mathrm{L}$. on the basis of leaf measurements. Silvae Genetica 11: 156-161.

Gill JA \& Davy AJ (1983) Variation and polyploidy within lowland populations of the Betula pendula/Betula pubescens complex. New Phytologist 94: 433-451.

IUCN (1994) Guidelines for protected area management categories. International Union for Conservation of Nature and Natural Resources, Glandm, Switzerland and Cambridge, UK.

IUCN (2014) The IUCN Red List of Threatened Species, Betula szaferi. International Union for Conservation of Nature and Natural Resources. Version 2014.3, http://www.iucnredlist.org/details/34308/0

Jensen RJ (2003) The conundrum of morphometrics. Taxon 52: 663-671.

Jentys-Szaferowa J (1953) Studia nad brzozą ojcowską (Betula oycoviensis Bess.). Ochrona Przyrody 21: 34-57.

Jentys-Szaferowa J (1967) Badania systematyczno-doświadczalne nad Betula oycoviensis Besser. Rocznik Sekcji Dendrologicznej Polskiego Towarzystwa Botanicznego 21: 5-56.

Jentys-Szaferowa J, Bialobrzeska M, Truchanowicz J \& Wieckowska I (1974) The second decade of investigations on Betula oycoviensis Bess. Fragmenta Floristica et Geobotanica 20: 203-242.

Johnsson H (1945) Interspecific hybridization within the genus Betula. Hereditas 31: 163-176.

Klingenberg CP (2010) Evolution and development of shape: integrating quantitative approaches. $\mathrm{Na}-$ ture Reviews Genetics 11: 623-635. doi:10.1038/ nrg2829.

Korczyk A (1967a) Rozmieszczenie geograficzne brzozy ojcowskiej (Betula oycoviensis Bess.). Ochrona Przyrody 32: 133-170.
Korczyk A (1967b) Brzoza ojcowska (Betula oycoviensis Bess.) w Dolinie Kobylańskiej. Fragmenta Floristica et Geobotanica 13: 493-497.

Krzaczek W \& Krzaczek T (1968) New locality of Betula oycoviensis Bess. in Poland. Fragmenta Floristica et Geobotanica 14: 155-156.

Kř́iž Z (1980) Poznámky k novým poznatkům o břízách na Chomutovsku. Památky - Příroda Život, Chomutov 12: 93-96.

Kř́iž Z (1981) K historii Betula oycoviensis Besser. Severočeskou přírodou 12: 37-46.

Kř́iž Z (2003) Betula L. - bříza: Květena České republiky, část II (ed. by S Hejný \& B Slavík) Academia, Praha, pp. 35-46.

Ondráček C (2008) Plán péče o prírodní památ$\mathrm{ku}$ - Lokalita břízy ojcovské u Volyně na období 2008-2017. www.kr-ustecky.cz/VismoOnline ActionScripts/File.ashx?id_org $=450018 \& i d$ dokumenty $=1647628$.

Parisod C, Holderegger R \& Brochmann C (2010) Evolutionary consequences of autopolyploidy. New Phytologist 186: 5-17.

Pawłowska L (1980a) Flavonoids in the leaves of polish species of the genus Betula L. - II. The flavonoids of B. "nova" and B. humilis Schrk. leaves. Acta Societatis Botanicorum Poloniae 49: 297-310.

Pawłowska L (1980b) Flavonoids in the leaves of polish species of the genus Betula L. - III. The flavonoids of B. oycoviensis Bess. leaves. Acta Societatis Botanicorum Poloniae 49: 311-320.

Pawłowska L (1983) Biochemical and systematic study of the genus Betula L. Acta Societatis Botanicorum Poloniae 52: 301-314.

R Development Core Team (2011) R: A language and environment for statistical computing. R Foundation for Statistical Computing, Vienna.

Ramsey J \& Schemske DW (1998) Pathways, mechanisms, and rates of polyploid formation in flowering plants. Annual Review of Ecology and Systematics 29: 467-501.

Schenk MF, Thienpont CN, Koopman WJM, Gilissen LJWJ \& Smulders MJM (2008) Phylogenetic relationships in Betula (Betulaceae) based on AFLP markers. Tree Genetics \& Genomes 4: 911-924. doi:10.1007/s11295-008-0162-0.

Seneta W \& Dolatowski J (1997) Dendrologia. Wydawnictwo Naukowe PWN, Warszawa.

Sołtys-Lelek A \& Barabasz-Krasny B (2009) Protected vascular plant species of Ojców National Park (S Poland): Rare, relict and endangered plants and fungi in Poland (ed. by Z Mirek \& A Nikel) W. Szafer Institute of Botany, Polish Academy of Sciences, Kraków, pp. 487-501.

Staszkiewicz J (1986) Betula szaferi - a new species of the genus Betula L. from Poland. Acta Societatis Botanicorum Polaniae 55: 361-366. 
Staszkiewicz J (2013) Brzoza ojcowska (Betula oycoviensis Bess.) na górze Skiełek w Beskidzie Wyspowym. http://www.brzozanaskielku.republika.pl

Staszkiewicz J \& Wójcicki JJ (1986) Ostatnie dwadzieścia lat w historii brzozy ojcowskiej [Betula $\times$ oycoviensis Besser (pro spec.)] w okolicach Krakowa. Chrońmy Przyrodę Ojczystą 42: 30-37.

Staszkiewicz J \& Wójcicki JJ (1992) "Betula ×oycoviensis" Besser in the environs of Kraków (S. Poland). Veröffentlichungen des Geobotanischen Institutes der Eidgenössische Technische Hochschule, Stiftung Rübel, in Zürich 107: 94-97.

Sýkora T (1983) Taxonomie a rozšíření bříz okruhu Betula alba v Českém masívu. Zprávy Československé botanické společnosti 18: 1-14.

Szwabowicz A (1971) Badania nad pyłkiem potomstwa brzozy ojcowskiej Betula oycoviensis. Acta Societatis Botanicorum Poloniae 40: 91-121.

Szwabowicz A (1972) Badania kariologiczne brzozy ojcowskiej i jej potomstwa. Acta Societatis Botanicorum Poloniae 41: 235-252.

Szwabowicz A (1976) Microsporogenesis of Betula oycoviensis Bess. and of its progeny. Acta Societatis Botanicorum Poloniae 45: 169-184.

Szaferowa J (1928) Brzoza ojcowska (Betula oycoviensis Bess.). Historia i charakterystyka gatunku.
Rocznik Polskiego Towarzystwa Dendrologicznego 2: 69-88.

ter Braak CJF \& Šmilauer P (2002) CANOCO reference manual and CanoDraw for Windows user's guide: software for canonical community ordination (version 4.5), Microcomputer Power, Ithaca, New York.

Thórsson ÆT, Salmela E \& Anamthawat-Jónsson K (2001) Morphological, cytogenetic, and molecular evidence for introgressive hybridization in birch. Journal of Heredity 92: 404-408.

Tolasz R, Tolasz R, Míková T, Valeriánová A \& Voženílek V (2007) Climate atlas of Czechia. Český hydrometeorologický ústav, Praha, Univerzita Palackého, Olomouc.

Turałówna K (1957) Nowe stanowisko brzozy ojcowskiej (Betula oycoviensis Bess.) w Polsce. Fragmenta Floristica et Geobotanica 3: 17-20.

Úradníček L, Maděra P, Tichá S \& Kobližek J (2009) Dřeviny České republiky. Lesnická práce, Kostelec nad Černými lesy, $2^{\text {nd }}$ and modified edition.

Viscosi V \& Cardini A (2011) Leaf Morphology, Taxonomy and Geometric Morphometrics: A Simplified Protocol for Beginners. PLoS ONE 6: 10: e25630. doi:10.1371/journal.pone.0025630. 